ĐORDANO MERLIKO, student doktorskih studija

Univerzitet Sapienca, Odsek za istoriju

Rim

UDK 94(4)"1914"

341.7(450:497.11)"1914"(093.2)

\title{
REAKCIJE NA SARAJEVSKI ATENTAT U ITALIJANSKIM DIPLOMATSKIM DOKUMENTIMA
}

Možda se u Beču traži izgovor da bi se okrivila Srbija?

Sanđulijano, 5. jul 1914.

\begin{abstract}
APSTRAKT: Cilj članka jeste da sagleda Sarajevski atentat i krizu koja je potom usledila u svetlu italijanskih diplomatskih dokumenata. Austrougarski prestolonaslednik Franc Ferdinand nije uživao velike simpatije što zbog svog karaktera, što zbog svojih reakcionarnih ideja, tako da njegova smrt nije pobudila veliku žalost, čak ni unutar Habzburškog carstva. Što se tiče političkih reakcija, vlada u Beogradu je zauzela odmeren stav kako bi izbegla pooštravanje odnosa sa Bečom. Nasuprot, austrougarske vladajuće klase čine se odlučnim u nameri da ubistvo prestolonaslednika iskoriste kako bi poravnali račune sa Srbijom i iredentističkim pokretima aktivnim u južnim delovima carstva. Demonstracijom moći Beč je težio da uguši izrazite nacionalne težnje na teritorijama pod svojom vlašću i povrati ugled koji je posle uspeha Srbije u Balkanskim ratovima bio uzdrman na tim prostorima.
\end{abstract}

Ključne reči: Sarajevski atentat, Bosna i Hercegovina, Srbija, AustroUgarska, Italija, Prvi svetski rat

Sve do poslednjih decenija 20. veka, vlade ujedinjene Italije su izdvajale Balkansko poluostrvo kao jednu od regija u kojoj mogu potvrditi svoj spoljnopolitički uticaj. U skladu sa svojim ambicijama, Italija se obezbedila jakom mrežom diplomatskih predstavništava koji su pokrili prestonice svih država na Balkanu, kao i važne oblasti za regionalnu politiku poput Mađarske, Albanije, Dalmacije, Bosne i Makedonije. Tako su italijanski dokumenti dobili na značaju u proučavanju istorije na Balkanu, kako zbog produbljivanja činjenica, tako i zbog njihove interpretacije i vrednovanja. Cilj ovog rada jeste da uz pomoć italijanskih diplomatskih dokumenata predstavi kontekst u kome se odigrao Sarajevski atentat 28. juna 1914, kao i reakcije na taj događaj u okviru Austro-Ugarske monarhije i na području Balkana. 


\section{Poseta Franca Ferdinanda Sarajevu kao upozorenje Srbiji}

U junu 1914. austrougarski prestolonaslednik Franc Ferdinand odlazi u posetu Sarajevu u funkciji glavnog inspektora oružanih snaga kako bi prisustvovao vojnim manevrima habzburške vojske u Bosni i Hercegovini. Izbor Bosne kao sedišta vojnih manevara posebno je bio motivisan političkim razlozima, i u analizama italijanskih posmatrača tog vremena ti razlozi su jasno navedeni. Potpukovnik Albrići, italijanski vojni ataše u Beču, piše: „Manevri su posebno bili traženi iz političkih razloga, rekao bih na inicijativu glavnog vojnog zapovednika Poćoreka, i u tom smislu podržani od nadvojvode prestolonaslednika i generala Konrada“. Iz perspektive zagovornika manevara, prema rečima Albrićija, oni „su morali da deluju kao upozorenje pansrpskim agitatorima, i da istovremeno pokažu na prostoru okupiranih regija i izvan njihovih granica austrougarsku vojnu spremnost na tim teritorijama". ${ }^{1}$

Istog mišljenja bio je i italijanski konzul u Sarajevu, Labija, koji smatra da: „Uz prisustvo nadvojvode i šefa vrhovnog štaba namerava se da se demonstrira Srbiji i Crnoj Gori, aktivnim u ovim regijama pogotovo nakon uspeha ostvarenih u Balkanskim ratovima, jedna prvenstveno smela propaganda, s druge strane se želi da se nadvojvodi ovom posetom, osmišljenom još u leto 1910. i odloženom zbog hladnog prijema koji je imao u Dubrovniku odakle je ovamo i trebalo da dođe, omogući prilika da se politički afirmiše i pred ovdašnjim stanovništvom". ${ }^{2}$

Italijanski konzul Labija takođe navodi da je dolazak nadvojvode i prestolonaslednika u Sarajevo upravo 28. juna, na dan najvećeg nacionalnog okupljanja Srba, u najmanju ruku bila „nesmotrenost“, ako ne i otvorena "provokacija“. 3

${ }^{1}$ Istorijski arhiv Vrhovnog štaba italijanske vojske (Ufficio storico dello stato maggiore dell'esercito [Aussme]), fond G29, fascikla 17. Izveštaji iz 1914. april/jun. Potpukovnik Albrići, Zapisi o manevrima u Bosni i Hercegovini, 30. jun 1914. Čini se da su italijanske diplomate tog vremena slabo razumele terminološku razliku između velikosrpskih i jugoslovenskih nastojanja. U posmatranim spisima često se upotrebljava pojam „pansrpski“ (it. panserbo) kojim su se želele objediniti ideje Južnih Slovena usmerene protiv Austro-Ugarske sa težnjom da se formira ujedinjena nezavisna država na toj teritoriji. Cilj rada nije terminološko razjašnjenje ovog pojma i u skladu sa tim termin je preveden najpribližnije onome kako je naveden u originalnom tekstu.

${ }^{2}$ Istorijski arhiv spoljnih poslova, (Archivio storico del Ministero degli Affari Esteri [Asmae]), Serie politica, 1891-1916, fascikla 104, dosije austro-srpski rat. Il Console in Sarajevo al Ministro degli affari esteri. Sarajevo, 4 luglio 1914.

${ }^{3}$ Ibidem. 


\section{Princip i Čabrinović}

Italijanski diplomatski dokumenti ne sadrže značajnije informacije o samoj dinamici atentata. Konzul u Sarajevu navodi: „Princip iz neposredne blizine ispaljuje dva hica iz revolvera Brovning koji ranjavanjem nadvojvode $\mathrm{u}$ karotidu i vojvotkinje $\mathrm{u}$ aortu dovode do njihove skoro trenutne smrti“. U svom izveštaju konzul Labija takođe beleži kratak opis dva atentatora. Čabrinović biva okarakterisan kao osoba sa "nemirnim i nasilnim“ temperamentom, „osrednje i rasejane“ pameti; on „bi štaviše bio dovoljno naivan, i onaj koji bi sve priznao". Izrazito drugačiji od Principa koji „je bio vanprosečno inteligentan, lukav, rezervisan, ciničan“, i tokom ispitivanja „čini se da nije izustio ni jednu jedinu reč koja bi ga izdala“. Labija podvlači veliku odgovornost vlasti zbog lakoće sa kojom se pristupilo organizaciji prestolonaslednikove posete. Italijanski konzul piše da je „beskorisno govoriti - uostalom pokazala se očiglednim - odgovornost vlasti (...) za smrt nadvojvoda, protiv koje se nije umela preduzeti nijedna spremna i efikasna mera, pogotovo nakon prvog atentata". ${ }^{4}$

Italijanske diplomate takođe smatraju da uzroke atentata delimično treba tražiti u iredentističkoj propagandi diktiranoj iz Srbije, kako je smatrao i Beč, ali i unutrašnjim prilikama u Bosni koja je bila podvrgnuta dominaciji Habzburga. Italijanski predstavnik u Srbiji piše da je propagandna kampanja sprovedena od strane Srbije „nesumnjivo uticala na povišenu svest dva mladića“ ali i dodaje da su se Princip i Čabrinović „žrtvovali zarad svog progonjenog naroda“. Slično ovome, ambasador u Beču ocenjuje da je „napad koji je koštao života nadvojvodu prestolonaslednika i njegovu suprugu (...) nesumnjivo bio počinjen od strane jednog Srbina da bi osvetio svoju potčinjenu nacionalnost u Austrougarskoj“. ${ }^{5}$

\section{Reakcije sa južnih prostora Austro-Ugarske}

Smrt prestolonaslednika nije imala značajnijih posledica u bosanskoj javnosti. Italijanski konzul u Sarajevu beleži: „Nedeljne navike, razonoda i veselost nisu usahnule tog tragičnog popodneva, iako su svi znali za atentat i njegove tragične posledice“. Italijanski diplomata smatra da je vrlo mali broj ljudi pokazao žaljenje zbog smrti prestolonaslednika, dok su štaviše mnogi bili zadovoljni. Po mišljenju Labije, atentat je proizveo „zadovoljstvo

\footnotetext{
${ }^{4}$ Ibidem.

${ }^{5}$ Asmae, Documenti diplomatici, serie XXII, Serbia 1913-1914. Il R. Incaricato d'affari in Belgrado al Ministro degli affari esteri. Belgrado, $1^{\circ}$ luglio 1914. Asmae, Serie politica, 1891-1916; fascikla 104, guerra austro-serba. L'Ambasciatore in Vienna al Ministro degli affari esteri. Vienna 2 luglio 1914.
} 
kod velikog broja i nezainteresovanost ostalog dela" bosanskog naroda. Sve u svemu, italijanski diplomata je držao do toga da je austrougarska administracija donela značajnu dobrobit Bosni i Hercegovini, ali ipak, Beč nije mogao da računa na lojalnost stanovništva koje je, bez obzira na versku pripadnost, ispoljavalo jasna iredentistička osećanja. U odgovarajućem trenutku ovo stanovništvo bi se u velikoj većini pokazalo voljno i spremno da pribegne na bilo koji način i po svaku cenu trijumfu pansprske ideje, ili da gleda potresenu Austro-Ugarsku monarhiju koja se njoj čini glavnom preprekom, zaključuje Labija. ${ }^{6}$

Za nijansu drugačija slika vidljiva je u Hrvatskoj i Slavoniji. Italijanski konzul u Rijeci izveštava da na tom prostoru Srbi nisu pokazali posebne emocije povodom smrti Franca Ferdinanda. Ipak, on izdvaja reakcije Hrvata $u$ zavisnosti od njihovog socijalnog statusa i godina. Među bogatima slojevima i omladinom Sarajevski atentat nije izazvao veliki utisak. Po rečima italijanskog diplomate to se objašnjava njihovom slabom povezanošću sa Habzburškom monarhijom i, u tim krugovima, podržanim jugoslovenskim nastojanjima: „Među višim staležima (...) pogotovo među mladima, srpske pobede nad Turcima i Bugarima imale su velikog uticaja, i moglo bi se reći da su se prosrpska osećanja među njima ukorenila, time poistovećujući njihove ideale sa idealima mnogobrojnog srpskog naroda rasejanog po Slavoniji“".

Sa druge strane atentat u Sarajevu je ostavio „duboki uticaj“ među seljacima, što se može objasniti značajem koji je crkva kod njih uživala. Tako italijanski diplomata objašnjava: „Obično stanovništvo u Hrvatskoj je bilo, i nastavlja da bude, pobožno i sasvim pod uticajem nižih slojeva sveštenstva koje je uvek nastojalo da održi budnim u dušama ova dva osećaja: ljubav prema Austriji i tradiciju negovanja kulta dinastije Habzburgovaca“. ${ }^{8}$

\section{Reakcije u Beču}

$\mathrm{Ni} \mathrm{u}$ Beču nasilna smrt prestolonaslednika nije izazvala veliku uznemirenost. Italijanski ambasador u Beču, Avarna, piše: „Na kraju neočekivana i tragična smrt prestolonaslednika, mogla je da pobudi kod bečkog i stanovništva monarhije saosećanje za svoje nesrećne sinove, i za nesrećnu sudbinu koja je istovremeno prekinula život nadvojvode i njegove supruge, ali ne i iskreno i duboko saučešće". ${ }^{9}$

\footnotetext{
${ }^{6}$ Ivi, Il Console in Sarajevo al Ministro degli affari esteri. Sarajevo, 4 luglio 1914.

${ }^{7}$ Ivi, Il Console in Fiume al Ministro degli affari esteri. Fiume, 23 luglio 1914.

${ }^{8}$ Ibidem.

${ }^{9}$ Ivi, L'Ambasciatore in Vienna al Ministro degli esteri. Vienna, 5 luglio 1914.
} 
Što zbog političke reakcionarnosti, što zbog svog karaktera, Franc Ferdinand je uživao male simpatije. Italijanski konzul u Budimpešti, Martin Frenklin, beleži: „Nadvojvoda Franc Ferdinand nije bio simpatičan. U vezi sa tim je zanimljiva jednoglasnost mišljenja. Čak i oni koji su mu bili najbliži nisu sačuvali za njega neku posebnu privrženost ili naklonost" ${ }^{10}$

Sa čisto političke tačke gledišta, podrška na koju je Franc Ferdinand mogao da računa bila je ograničena na pripadnike visokih činova u vojsci i crkveni stalež. Italijanski konzul u Budimpešti navodi da se oko naslednika trona formirala „crkveno-vojna partija“. ${ }^{11}$ Van tog kruga nadvojvoda nije pobudio velike simpatije. Ambasador Avarna piše da je liberalno javno mnjenje stalno kritikovalo „sklonost pokojnog nadvojvode koju je gajio prema Jezuitima i konstantnu podršku koju je davao crkvenim udruženjima i socijalno-hrišćanskoj partiji“; od strane buržoazije „pokojni nadvojvoda je smatran za lidera klerikalne stranke i tako viđen sa dozom straha“. Austrougarska aristokratija se protivila njegovom braku iz ljubavi sa kneginjom Sofijom, kojim je narušio običaje dvora. Kao rezultat toga, prestolonaslednikova pojava je "generalno od strane različitih partija, sa izuzetkom onih hrišćansko-socijalnih, i hrišćansko-feudalnih, doživljavana sa određenom nelagodnošću“. ${ }^{12}$

$\mathrm{Ni} \mathrm{u}$ vojnim krugovima nadvojvoda nije uživao velike simpatije. Avarna izdvaja dve različite struje među njima. Prva, sačinjena od Vrhovnog štaba vojske koji je prema Francu Ferdinandu gajio „određenu vrstu poštovanja“ ali se radilo o strahopoštovanju, "strahu da se padne u njegovu nemilost i da se tako beznadežno kompromituje karijera“. Druga struja bila je sastavljena „u većini od oficira armije i oficira mornarice“. Nadvojvodi oni nisu oprostili „njegovo nasilno i bezobzirno ponašanje“, i „optuživali su ga da je često, za vreme manevara, bio štaviše brutalan u svojim sudovima o generalima, koji su, i pored toga što su počinili pokoju grešku, imali pravo da očekuju objektivnije ocene." ${ }^{13}$

Na dvoru, car Franc Jozef mu nikada nije oprostio brak sa Sofijom Hotek, čiji je društveni rang bio niži od onoga što se smatralo poželjnim za suprugu prestolonaslednika. Italijanski konzul u Budimpešti piše: „Nadvojvoda nije bio preterano omiljen od strane starog cara, i sigurno nije bio omiljen od većeg dela prinčeva, od kojeg su se mnogi od njega udaljili još od vojske". ${ }^{14}$

\footnotetext{
${ }^{10}$ Ivi, Il Console a Budapest al Ministro degli esteri. Budapest, 8 luglio 1914.

${ }^{11}$ Ibidem.

${ }^{12}$ Ivi, L'Ambasciatore in Vienna al Ministro degli affari esteri. Vienna, 5 luglio 1914.

${ }^{13}$ Ibidem.

${ }^{14}$ Ivi, Il Console generale a Budapest, Martin Franklin, al Ministro degli esteri. Budapest, 8 luglio 1914.
} 
Još oštrije bile su reakcije $u$ drugoj prestonici carstva. Konzul $u$ Budimpešti izveštava da „su u Mađarskoj (...) sve klase na njega gledale sa antipatijom, zato što se znalo da nije imao ni malo naklonosti prema mađarskom narodu i zato je uvek izbegavao da poseti ovu zemlju", kao i da je želeo da ograniči ulogu koju su Mađari imali u okviru carstva. Posle atentata, italijanski konzul izveštava da „nisu bili malobrojni oni koji su juče $u$ Budimpešti rekli: „Sada Franc Jozef može mirno da umre zarad budućnosti svoje dinastije i svojih naroda“. Konzul dodaje da "mađarska štampa ne sakriva ovakav stav". ${ }^{15}$

\section{Posledice smrti Franca Ferdinanda}

Različiti posmatrači su složni u uverenju da su posledice atentata mogle biti pozitivne za tadašnju Evropu. U britanskom ministarstvu spoljnih poslova smatraju da bi smrt prestolonaslednika mogla da „pojednostavi mnoga alarmantna i problematična pitanja" u međunarodnoj politici, piše italijanski predstavnik u Londonu. ${ }^{16}$ Ambasador u Berlinu Bolati navodi da „ličnost austrijskog prestolonaslednika nije bila takva da posle svega čak i ovde probudi potpunu lojalnost". Nemački podsekretar spoljnih poslova Cimerman u poverenju iznosi italijanskom diplomati svoja razmišljanja o ubijenom nadvojvodi i o mogućim posledicama njegove smrti. Nadvojvoda Ferdinand ,je imao velike antipatije i predrasude: prema Mađarima, Italijanima, prema svemu onome što je liberalno; bio je promenljive naravi, nasilan, sklon isključivim i reakcionarnim uticajima“. Italijanski ambasador Bolati zaključuje da „bi se moglo poverovati da je njegov nestanak mnogo više pojednostavio nego što je dodatno iskomplikovao situaciju unutar i van monarhije“. ${ }^{17}$

\section{Antisrpsko nasilje}

U Bosni veći deo populacije ostao je ravnodušan prema smrti Franca Ferdinanda. Ipak, posle atentata počinju demonstracije i nasilje upereni protiv Srba. Konzul u Sarajevu, Labija, piše da je 28. juna „stotinak stude-

${ }^{15}$ Ibidem. I Documenti Diplomatici Italiani (Italijanski diplomatski dokumenti). 12: 28 giugno - 2 agosto 1914. Roma: Instituto Poligrafico dello Stato, 1964, (dalje DDI). Il Console generale a Budapest, Martin Franklin, al Ministro degli esteri Di Sangiuliano. 29 giugno 1914.

${ }^{16}$ Asmae, Documenti diplomatici, serie XXII, Serbia 1913-1914. Il R. Ambasciatore in Londra al Ministro degli affari esteri. Londra, 8 luglio 1914. Takođe videti: Asmae, Serie politica, 1891-1916; fascikla 104, guerra austro-serba, Il Ministro degli affari esteri agli Ambasciatori a Berlino, Londra, Vienna e Pietroburgo. Roma, 14 luglio 1914.

17 DDI, Il Ministro a Berlino, Bollati, al Ministro degli esteri, di Sangiuliano. Berlino, 30 giugno 1914. 
nata pokušalo da organizuje demonstracije koje nisu uspele da podgreju veći deo ravnodušne javnosti“; 29. juna nasilne demonstracije su ponovljene uz učešće ograničenog broja osoba, ,nekoliko stotina mladih i rulje koja je nastavila da uništava sve što se nalazilo u radnjama, školama i kućama koje su bile u vlasništvu Srba". U nekim slučajevima Srbi iz Sarajeva su da bi odbranili sopstveni život i svoju imovinu pribegavali oružju nanoseći telesne povrede demonstrantima, ili čak i smrt. ${ }^{18}$

Odnos vlasti prema nasilju, prema oceni italijanskog konzula, bio je takav da „uprkos malom broju i lošoj organizovanosti rulje, nije se desio nikakav efikasan otpor nadbrojnijih interventnih snaga“. Vlasti su „ako ne organizovano, onda sa predumišljajem tako postupile“, zaključuje konzul. Prema svedočenju Labije, jedna od žrtava je bila isprovocirana od strane habzburških snaga bezbednosti, i potom ubijena ispred kuće Čabrinovića, a u pitanju je bio Hrvat za koga su verovali da je Srbin. ${ }^{19}$ U svom sledećem izveštaju piše da je lično, zajedno sa nemačkim kolegom, imao priliku da posmatra kako su demonstranti pred očima policije nastavili sa pustošenjima. ${ }^{20}$

Nemački konzul u Sarajevu 29. juna navodi da je Sarajevo preživelo svoju Vartolomejsku noć upoređujući ono što se desilo sa masakrom u Francuskoj 1574. godine u kontekstu verskih ratova. Sa svoje strane italijanski konzul procenjuje da šteta napravljena u noći $28 / 29$. juna iznosi oko deset miliona kruna, dodajući da su mnogi srpski građani u Sarajevu već bili očajni i da „mnogi od njih ostaju u potpunoj bedi“. Pogođeni nisu bili samo oni osumnjičeni da su učestvovali u atentatu, niti oni poznati po svojim aktivnostima protiv vlade. Ciljalo se na Srbe uopšte, uključujući i dobrostojeće koji, tradicionalno, nisu podržavali političke projekte protiv vlade i koji su zbog tog razloga gledani sa podozrenjem od strane pripadnika Mlade Bosne. U nekim slučajevima, srpsko stanovništvo je na atentat reagovalo tako što je negiralo svoje učešće u tome, ponovo potvrđujući lojalnost habzburškoj dinastiji. Ovakav stav je u nekoliko navrata bio izražen i upečatljivim gestovima; arhiepiskop Pravoslavne crkve u Sarajevu poistovećuje Principa i Čabrinovića sa Antihristom, dok je na početku rata deo Srba, da bi pokazao svoju lojalnost, dobrovoljno pristupio austrougarskoj vojsci. $^{21}$

${ }^{18}$ Asmae, Serie politica, 1891-1916; fascikla 104, guerra austro-serba. Il Console in Sarajevo al Ministro degli affari esteri. Sarajevo, 4 luglio 1914. Ivi, Il Console in Sarajevo al Ministro degli affari esteri. Sarajevo, 30 giugno 1914.

${ }^{19}$ Ibidem.

${ }^{20}$ Ivi, Il Console in Sarajevo al Ministro degli affari esteri, 4 luglio 1914.

${ }^{21}$ A. Mitrovic, Serbia's great war, 1914-1918. London: Hurst, 2007, p. 18. Asmae, Serie politica, 1891-1916; fascikla 104, guerra austro-serba, Il Console in Sarajevo al Ministro degli affari esteri. Sarajevo, 30 giugno 1914. V. Dedijer, Road to Sarajevo. New York: Simon and Schuster, 1966, p. 340 i 328. 
Antisrpske demonstracije se održavaju u Hrvatskoj i Slavoniji, gde je, kao i u Bosni, brojnost učesnika ograničena. Sa druge strane, nacionalističke i klerikalne grupe pokušavale su da iskoriste antisrpsku klimu da bi dobile na sopstvenoj važnosti. Italijanski konzul u Rijeci izveštava da je čak i u zagrebačkom parlamentu izvesna manjina podstakla „nasilna prekidanja i pobunu" protiv srpskog poslanika Medakovića, predsednika i uticajnog člana srpsko-hrvatske koalicije. Ne toliko zbog žalosti povodom ubistva Franca Ferdinanda, takvo ponašanje bilo je više motivisano željom da se „iskoristi okolnost“. Uticaj Hrvatske stranke prava bio je smanjen, dok je u parlamentu u Zagrebu dominirala srpsko-hrvatska koalicija, tumač političkih i kulturnih težnji za ujedinjenjem srpskih i hrvatskih zahteva. Smrt nadvojvode i talas antisrpskih reakcija od strane štampe i habzburške vlasti u parlamentu, „podržan od strane sveštenstva i austrijskog klerikalizma“, uzdrmali su srpsko-hrvatsku koaliciju. ${ }^{22}$

\section{Reakcije u Srbiji}

Na političkoj sceni Srbije bilo je i onih koji su smatrali da je smrt Franca Ferdinanda pozitivan faktor koji može olakšati odnose između Beča i Beograda. Srpski ambasador u Parizu Milenko Vesnić je ocenio da će prestankom negativnog uticaja nadvojvode Austro-Ugarska zauzeti mudriji stav prema Beogradu. Ipak, srpskim vlastima u klimi povišene napetosti u odnosima dveju zemalja ne izmiče da bi atentat u Sarajevu mogao da provocira pogoršanje tih odnosa. Kora, italijanski otpravnik poslova u Beogradu, piše da je Sarajevski atentat u srpskim političkim krugovima provocirao „duboku zabrinutost zbog posledica koje bi mogle nastati (...) u odnosima sa vladom Austrougarske zbog odmazde i progona" Srba na toj teritoriji. ${ }^{23}$ Srpska vlast je nastojala da izbegne komplikovanje odnosa sa Bečom. Drugačija je bila reakcija naroda; predstavnik Austro-Ugarske u Beogradu, fon Štork, izveštava da se „na ulicama i u kafanama, bodre našom nesrećom kao božjim znakom i pravednom kaznom za sve nesreće koje je Austrija nanela Srbiji“. Ovakav stav izriče i italijanski predstavnik na Cetinju, koji piše da je smrt Franca Ferdinanda prouzrokovala u Crnoj Gori ,javno žaljenje od strane vladajućih krugova (koji su ga čak i previše pokazali da bi bilo iskreno), dok je narod gajio simpatije prema potčinjenim Slovenima unutar austrougarskog carstva“. ${ }^{24}$

${ }^{22}$ Asmae, Serie politica, 1891-1916; fascikla 104, guerra austro-serba. Il Console in Fiume al Ministro degli affari esteri. Fiume, 23 luglio 1914.

${ }^{23}$ DDI, L'ambasciatore a Parigi, Tittoni, al Ministro degli esteri, Di Sangiuliano. Parigi, 5 luglio 1914. Asmae, Serie politica, 1891-1916; fascikla 104, guerra austro-serba, L'Incaricato d'affari in Belgrado al Ministro degli affari esteri. Belgrado, $1^{\circ}$ luglio 1914.

${ }^{24}$ A. Mitrovic [2007], p. 9. Asmae, serie politica, fascikla 199. L'Incaricato d'affari in Cettigne al Ministro degli affari esteri. Cettigne, 9 luglio 1914. 
Austrougarski diplomatski kor u Beogradu pokazuje otvorenu netrpeljivost prema Srbiji, opuženoj da je delimično odgovorna za ubistvo prestolonaslednika Franca Ferdinanda. U razgovorima sa italijanskim predstavnicima habzburške diplomate iznose „najoštrijim rečima“ svoje ogorčenje prema Beogradu. Otpravnik poslova Kora govori o „nadobudnoj uzbuđenos-

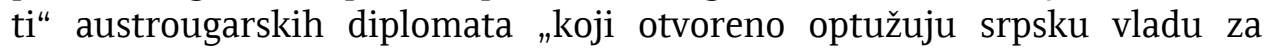
učešće u zaveri“. Austrougarska ambasada prigovara i zbog navodnih opasnosti u kojima se mogu naći diplomate ili obična lica austrougarske nacionalnosti koji žive u Srbiji. Iako neosnovani, takvi strahovi doprinose stvaranju jaza u javnom mnjenju i netrpeljivosti u odnosima sa Srbijom i, kao rezultat, „najvišu tenziju u odnosima, već dovoljno zategnutim, između dva naroda“. ${ }^{25}$

Srpske vlasti uspevaju da zadrže oprezan stav. Italijanski predstavnik u Beogradu piše: „Srpska vlada je sigurna da šta god da se desi ima podršku Rusije, drži se smireno i gleda da izbegne bilo kakvu komplikaciju sa austrougarskom vladom, uzdržavajući se čak i da uloži protest zbog demonstracija ispred srpskog predstavništva u Beču tokom kojih su bile spaljene različite srpske zastave“. ${ }^{26}$ Povremeno, Srbija upućuje po koje upozorenje. Ministarstvo spoljnih poslova u Beogradu obaveštava italijanskog predstavnika da antisrpsko nasilje pogoršava situaciju u Bosni i da se, ako uskoro ne prestane, ubuduće ne može isključiti još atentata. ${ }^{27}$

\section{Političke reakcije iz Beča}

Italijanski diplomati nisu verovali da bi atentat mogao da izazove rat u Evropi, čak ni rat između Srbije i Austro-Ugarske. Značajno je da u periodu posle atentata ministar spoljnih poslova Italije Sanđulijano pokazuje izvesnu zahvalnost zbog činjenice da je nestanak nadvojvode rešio spor oko Villa d'Este. Smeštena u blizini Rima, ova vila je bila u vlasništvu nadvojvode i u toku su bili pregovori sa italijanskim vlastima o njenom otkupu, što je bio očigledno marginalan problem. ${ }^{28}$ Sanđulijano takođe smatra da

${ }^{25}$ Asmae, Serie politica, 1891-1916; fascikla 104, guerra austro-serba. Il Ministro degli affari esteri all'Ambasciatore in Berlino. Roma, 5 luglio 1914. Asmae, Documenti diplomatici. Serie XXII, Serbia 1913-1914. Il R. Incaricato d'affari in Belgrado al Ministro degli affari esteri. Belgrado, 15 luglio 1914.

${ }^{26}$ Ivi, Il R. Incaricato d'affari in Belgrado al Ministro degli affari esteri. Belgrado, 4 luglio 1914.

${ }^{27}$ Ibidem.

28 A. Salandra, La neutralità italiana 1914-1915. Ricordi e pensieri. Milano: Mondadori, 1928, p. 16. Salandra, predsednik italijanske vlade od 1914. do 1916, takođe navodi da se Sarajevski atentat „čini kao novi opasan element koji bi ugrozio bezbednost“, ali ne i razlog koji bi prouzrokovao rat; ivi, p. 63. 
atentat u Sarajevu može imati i pozitivne posledice na produbljivanje odnosa Rima i Beča. Na kraju krajeva, nestao je „onaj koji je bio poznat kao najveći protivnik politike u korist Italije u Austriji“. U ovim komentarima ne čini se da postoji i najmanja sumnja o predstojećem ratu. ${ }^{29}$

Ipak, italijanske diplomate će ubrzo uočiti uzbuđenje u vrhu Habzburškog carstva. Vojni ataše u Beču piše 2. jula: „Uzbuđeni vojni krugovi jednoglasni su u tome da bi bilo neophodno završiti sa Srbijom“. Čak i pre početka zvanične istrage, Beč predstavlja atentat kao zaveru srpskih nacionalista, čije organizatore treba tražiti direktno u Beogradu. Habzburškim vlastima atentatori su priznali da su motivi za njihov gest nacionalnog karaktera - oni su težili južnoslovenskoj emancipaciji u odnosu na Beč i ujedinjenju Jugoslovena. Oni takođe uključuju društveno-političke razloge, kao što su patnje bosanskih kmetova, izražavajući svoja anarhistička i socijalistička uverenja. ${ }^{30} \mathrm{U}$ Austro-Ugarskoj, složenost njihove motivacije, što u štampi što u diplomatskim razgovorima sa stranim diplomatama, biva lukavo predstavljena kao zavera srpskih nacionalista. U Beču se prećutkuje učešće hrvatskih i bošnjačkih atentatora, ne bi li se što jasnije Srbija povezala sa zaverenicima. ${ }^{31}$

Već 29. juna, italijanski konzul u Sarajevu piše da vlasti veruju kako je atentat bio plod „plana pansrpskih nacionalista“, diktiranog od strane Beograda, „gde je sve bilo pripremljeno u skladu sa određenim planom“. Od samog početka stav Beča podržava nemačka vlada, koja dodatno podupire tezu o odgovornosti Beograda. ${ }^{32}$ Srpska krivica zatim biva potvrđena u propagandnoj kampanji u kojoj austrougarska štampa utire put predstojećem ratu. Po rečima italijanskog konzula u Budimpešti, čak i poluzvanični listovi iznose sudove koji „su apsolutno upereni protiv Srbije“. Dana 7. jula itali-

${ }^{29}$ Asmae, Serie politica, 1891-1916; fascikla 104, guerra austro-serba. Il Ministro degli esteri, di Sangiuliano, agli ambasciatori. Roma, $1^{\circ}$ luglio 1914. DDI, L'ambasciatore a Berlino, Bollati, al Ministro degli esteri, di Sangiuliano. Berlino, 8 luglio 1914.

${ }^{30}$ Asmae, Serie politica, 1891-1916; fascikla 104, guerra austro-serba. Telegramma dell'addetto militare a Vienna allo Stato Maggiore, 2 luglio 1914. V. Dedijer [1966], p. 33841. O idejama Mlade Bosne videti: ivi, pp. 337-41. Značajno je da Srbija potencira političke ideje dvojice atentatora. Srpski ambasador u Beču ponavlja austrijskoj vladi da „učinilac ovog atentata je anarhista, usamljen“; Poslanstvo Kraljevine Srbije u Austro-Ugarskoj - Beč - Ministarstvu inostranih dela. 20. VI/3. VII 1914. Dokumenti o spoljnoj politici Kraljevine Srbije. Knjiga VII, Sveska 2. Srpska akademija nauka i umetnosti. Beograd: 1980.

31 DDI, L'ambasciatore a Vienna, Avarna, al Ministro degli esteri, di Sangiuliano. Vienna 29 giugno 1914. Dedijer [1966], p. 342; Asmae, Documenti diplomatici. Serie XXII, Serbia 1913-1914. Il R. Ambasciatore in Vienna al Ministro degli affari esteri. Vienna, 9 luglio 1914.

32 DDI, Il console a Sarajevo, Labia, al Ministro degli esteri, di Sangiuliano. Sarajevo, 29 giugno 1914. Ivi, L'ambasciatore a Vienna, Avarna, al Ministro degli esteri, di Sangiuliano. Vienna 29 giugno 1914. 
janski ambasador u Beču izveštava da „antisrpski diskurs u austrougarskoj štampi nema namere da se prekine, i štaviše polako se uvećava intenzitet kojim bivaju objavljena nova otkrića" o atentatu u Sarajevu. ${ }^{33}$ Samo izdanja socijalista, poput Arbeiter Zeitung i u manjoj meri liberala poput Zeit i Neue Freie Presse uzdržavaju se od ratnohuškačke kampanje.

U propagandnom ratu vođenom po novinama bilo je malo prostora za precizne rekonstrukcije događaja, dok se sa druge strane preterivalo i krivotvorilo ono što je bilo u vezi sa atentatom. Austrougarska štampa najavljuje ujedinjenje Srbije i Crne Gore, izveštavajući da Rusija instalira vojnu bazu na crnogorskoj obali. Mada su ovakve vesti italijanske diplomate redovno demantovale, one su povećavale zabrinutost u javnosti. Reichpost piše, sa naglašenim besom, da je na dan ubistva Franca Ferdinanda u ruskoj ambasadi u Beogradu priređen prijem. Italijanski predstavnik u Srbiji koji je bio prisutan u ruskoj ambasadi navodi da „je prijem bio ograničen na uobičajeni nedeljni bridž“. ${ }^{34}$

\section{Od istrage do rata}

Italijanski predstavnik u Beogradu, sada već shvata namere Habzburškog carstva. Kora piše da se „igra“ Beča sastoji u „tome da se okrivi vlada i narod u Srbiji, koristeći tragediju u Sarajevu u političke svrhe". „Jasno je da Austrija pokušava da iskoristi ovu priliku da se oslobodi političkih ličnosti, uznemiravajućih zbog njihovih budnih i redovnih akcija protiv administracije u Bosni i Hercegovini i zbog ometanja srpskohrvatskog bloka. Optužbe majora Pribićevića (koji je bolestan već nekoliko meseci) zato što je brat poslanika [Svetozara Pribićevića], hapšenje gospodina Jeftanovića, koji je tast srpskog ministra u Petrogradu Spalajkovića, poznatog austrofoba, optužbe generala Jankovića, predsednika i duše „Narodne odbrane". ${ }^{35}$

U međuvremenu srpska štampa reaguje na napade austrougarske štampe, no Srbija nastoji da ostane smirena: „Uprkos uznemirenosti svih duša zbog ekscesa rulje protiv Srba u Bosni i Hercegovini, uprkos optužbama

${ }^{33}$ Asmae, Serie politica, 1891-1916; fascikla 104, guerra austro-serba, Martin Franklin, Budapest, 4 luglio 1914. Ivi, L'Incaricato d'affari in Vienna al Ministro degli affari esteri. Vienna, 7 luglio 1914.

${ }^{34}$ Asmae, serie politica, fascikla 199. L'Incaricato d'affari in Cettigne al Ministro degli affari esteri. Cettigne, 9 luglio 1914; DDI, L'ambasciatore a Pietroburgo, Carlotti, al Ministro degli esteri, di Sangiuliano. Pietroburgo, 18 luglio 1914. Asmae, Documenti diplomatici. Serie XXII, Serbia 1913-1914. Il R. Incaricato d'affari in Belgrado al Ministro degli affari esteri. Belgrado, 15 luglio 1914.

35 Asmae, Serie $P$ politica, 1891-1916; fascikla 104, guerra austro-serba. L'Incaricato d'affari in Belgrado al Ministro degli affari esteri. Belgrado, 7 luglio 1914. 
i najtežim uvredama od strane austrougarske i nemačke štampe, koje su opisale Beograd kao jazbinu ubica, uprkos insinuacijama o dosluhu te iste vlade o zaveri koja će ovde biti organizovana, ipak vlada i javno mnjenje su uspeli da zadrže miran i uzdržan stav, pokušavajući da izbegnu bilo kakve izgovore za žalbe od strane Austrije“. ${ }^{36}$

Kora smatra, međutim, da je Srbija duboko potresena aktuelnim događajima: „Kakav god bio epilog ovih bolnih događaja, već sada bi se moglo reći da su reakcije i progoni koje su pratili atentat u Sarajevu još više povećali, ako je to moguće, neumoljivu mržnju srpskog naroda prema Austro-Ugarskoj. Od svega što se do sada desilo, kaže svaki Srbin, mi ćemo zapamtiti dan svođenja računa. Tako, dok je svim naporima vlade i diplomatije dugo trebalo da unaprede odnose između Srbije i Austrije, tragična sudbina i uporna politika ugnjetavanja i zastrašivanja protiv jednog patriotskog naroda, uništila je u trenutku težak rad i produbila ponor koji je razdvajao Srbiju od susedne monarhije". ${ }^{37}$

Zvanično, Beč čeka rezultate istrage da utvrdi sledeće korake, no sada se pojavljuje ideja da se sprovede istraga i na srpskoj teritoriji - delikatan zahtev koji bi ugrozio suverenitet srpske države. ${ }^{38}$ Prvi put kada habzburška diplomatija objavljuje istragu ona to čini na neformalan način, 30. juna. Italijanski predstavnik u Srbiji piše da Beč nije podneo zvaničan zahtev „već kao privatnu stvar poverenu ovom otpravniku generalnog sekretara spoljnih poslova, kao da je reč o nasilnoj svađi između dvojice“. Nekoliko dana kasnije, ambasador u Beogradu prenosi reči srpskog premijera Pašića, koji sažeto navodi da „ako Austrougarska traži casus belli, nema šta drugo nego da zatraži zajedničku istragu“. ${ }^{39}$

Postepeno, namere austrougarske vlade postaju jasne; 5 . jula ministar spoljnih poslova Italije Sanđulijano izražava sumnju da se u Beču „traži izgovor da bi se okrivila Srbija“. ${ }^{40} \mathrm{~S}$ vremenom sumnje rastu, a 15. jula ambasador u Srbiji potvrđuje: „Izgleda da Austrija želi da preobrati proces iz Sarajeva, koji bi trebalo da bude suđenje dvojici ubica, u suđenje ideji

${ }^{36}$ Ibidem.

${ }^{37}$ Ibidem.

${ }^{38}$ Komentarišući ultimatum od 23. jula pravni savetnik italijanskog ministarstva spoljnih poslova piše da „austrougarski akt (...) postaje najnoviji slučaj direktne intervencije jedne države u domenu suvereniteta druge države“. Asmae, Serie politica, 1891-1916; fascikla 104, guerra austro-serba. Ufficio del contenzioso e della legislazione. Roma, 25 luglio 1914.

${ }^{39}$ Asmae, Serie politica, 1891-1916; fascikla 104, guerra austro-serba, L'Incaricato d'affari in Belgrado al Ministro degli affari esteri. Belgrado, $1^{\circ}$ luglio 1914 . Asmae, Documenti diplomatici. Serie XXII, Serbia 1913-1914. Il R. Ambasciatore in Belgrado al Ministro degli affari esteri. Belgrado, 11 luglio 1914.

40 Asmae, Serie politica, 1891-1916; fascikla 104, guerra austro-serba. Il Ministro degli affari esteri alle Regie Ambasciate di Vienna e Berlino. Roma, 5 luglio 1914. 
pansrpstva i Srbiji, i da time ubrza neizbežan sukob“. Sutradan on dodaje: „Sasvim je jasno da dok srpska vlada pokušava da na svaki način izbegne konflikte, u Austriji, naprotiv, gledaju da održe živim nemire". ${ }^{41}$

Konačno, 17. jula, Sanđulijano uklanja bilo kakve sumnje u pogledu namera Beča: „Shvatam da će Austro-Ugarska, podržana od strane Nemačke, uz to obe uverene da Rusija neće učiniti ništa, nametnuti Srbiji neprihvatljive uslove kako bi imala izgovor da je napadne i uništi, verovatno pripojivši potom sebi još neutvrđene teritorije“. ${ }^{42}$

Italija je svesna da su zahtevi Beča formulisani Beogradu na neprihvatljiv način, i da rezultat toga mora biti njihovo odbijanje od srpske strane. Neispunjavanje tih uslova habzburškoj vladi pruža izgovor za objavu rata. U ovom scenariju ne spominje se intervencija Rusije. Nemačka i Austro-Ugarska veruju, preciznije ponašaju se kao da veruju, kako Petrograd neće intervenisati. Ipak uprkos uverenjima Beča i Berlina, koji pokušavaju da pridobiju Rim, italijanska diplomatija jasno sagledava da će se konflikt proširiti. Italijanski predstavnik u Rumuniji Fašoti piše: „Ne čini mi se verovatnim da bi Nemačka (...) mogla da se pretvara da bi Rusija, čak i želeći, mogla da ostane neaktivna pred austrougarskom agresijom protiv Srbije. Dakle ako je Nemačka pratila Austriju u njenoj agresiji to bi značilo da je u to uključila rusku intervenciju“". ${ }^{43}$

Što se tiče razloga koje navodi Beč, italijanski konzul u Sarajevu šalje 24. jula Rimu duži izveštaj o iredentističkim težnjama u južnoslovenskim provincijama carstva. Mada je prethodnog dana Srbiji postavljen ultimatum, Labija navodi zahteve Beča $u$ formi hipoteza; dakle tekst je napisan kada se još uvek nisu znale posledice takvog čina. Pošto je opisao ciljeve i snagu jugoslovenske ideje, Labija zaključuje: „Austrija ima samo jedan put za spasenje ili barem primirje i taj put je odlučujuća ogromna demonstracija moći“" ${ }^{44}$

U italijanskim diplomatskim dokumentima vidi se jasna namera Austro-Ugarske da objavi rat Srbiji, kao i razlike u provokatorskom stavu Beča u odnosu na uzdržan stav Beograda tokom julske krize. Uzdrmana unutrašnjim krizama prouzrokovanim različitim nacionalnim previranjima,

${ }^{41}$ Asmae, Documenti diplomatici. Serie XXII, Serbia 1913-1914. Il R. Incaricato d'affari in Belgrado al Ministro degli affari esteri. Belgrado, 15 luglio 1914. DDI, L'incaricato d'affari a Belgrado, Cora, al Ministro degli esteri, Di Sangiuliano. Belgrado, 16 luglio 1914.

${ }^{42}$ DDI, Il Ministro degli esteri, di Sangiuliano, agli ambasciatori a Berlino, Bollati, a Pietroburgo, Carlotti, a Vienna, Avarna, e al ministro a Bucarest, Fasciotti. Fiuggi, 17 luglio 1914.

${ }^{43}$ DDI, Il ministro a Bucarest, Fasciotti, al Ministro degli esteri, di Sangiuliano. Bucarest, 18 luglio 1914.

${ }^{44}$ Asmae, Serie politica, 1891-1916; fascikla 104, guerra austro-serba. Il Console in Sarajevo al Ministro degli affari esteri. Sarajevo, 24 luglio 1914. 
Austro-Ugarska monarhija je imala potrebu da uspostavi unutrašnji red i potvrdi svoj status moćne sile u Evropi. Upravo na balkanskim prostorima njena moć je bila najuzdrmanija. Među južnoslovenskim narodima, pogotovo omladinom, širili su se nezadovoljstvo, revolucionarne ideje i otpor. Čak i pre 28. juna 1914. takva nastojanja bila su manifestovana, između ostalog, i različitim pokušajima atentata na habzburške zvaničnike u Bosni i Hrvatskoj. Tome je pogodovao značaj uloge koju su dobijale Srbija i Crna Gora, koje su u Balkanskim ratovima znatno proširile svoju teritoriju i dobile na važnosti u širenju ustaničkih ideja među potčinjenim narodom u južnim delovima Austro-Ugarske. U tom kontekstu, Sarajevski atentat je za Beč bio prilika da se objavi rat Srbiji - rat o kome se u više navrata razmišljalo u vladajućim austrougarskim krugovima. Podržan od Nemačke u slučaju izbijanja konflikta, kao i od inostrane javnosti zahvaljujući stalnim optužbama na račun srpske vlade, Beč je nameravao da demonstracijom sile zaustavi „proces slabljenja i raspada“, koji je italijanski ministar spoljnih poslova Sanđulijano smatrao neizbežnim. Ovakvu interpretaciju događaja u svojim sećanjima navodi i Salandra, predsednik italijanske vlade, 1914. godine. Sa naznakama zadovoljstva Salandra zaključuje: „Potez koji se vladi Austrougarske čini neophodnim za njen spas od brze propasti (...) umesto toga rezultira njenim samoubistvom" ${ }^{45}$

Giordano Merlicco

\section{THE REACTIONS ON THE SARAJEVO ASSASSINATION \\ IN THE ITALIAN DIPLOMATIC SOURCES}

\section{Summary}

The article provides an overview of the Sarajevo atentat and the following Austro-Serbian crisis, as they are described in Italian diplomatic documents. Both for his character and his reactionary beliefs, Franz Ferdinand was widely unpopular; that's why his death doesn't provoke much regret in Europe, nor in Austria itself. The Italian Government doesn't expect that assassination would lead to war. However, Italian diplomats soon notice that the Austro-Hungarian empire is eager to use the archduke's assassination as a pretext in order to wage war against Serbia. Such a move is considered by Italian diplomats as the only way the Habsburg Empire can halt the national movement of the Yugoslavs living in the dual monarchy and thus reassert its role as a great power. Italy is also aware that Russia will intervene to help Serbia and that the Austro-Serbian war will inevitably lead to a European conflict.

${ }^{45}$ DDI, Il Ministro degli esteri, di Sangiuliano, all'ambasciatore a Berlino, Bollati. Roma, 14 luglio 1914; A. Salandra [1928], p. 25. 